Relations industrielles

Industrial Relations

\title{
Worker Participation: Sucess and Problems, by Hem C. Jain, New York, Praeger Publishers, 1980, 358 pp.
}

\section{Jacques Bélanger}

Volume 36, numéro 3, 1981

URI : https://id.erudit.org/iderudit/029191ar

DOI : https://doi.org/10.7202/029191ar

Aller au sommaire du numéro

Éditeur(s)

Département des relations industrielles de l'Université Laval

ISSN

0034-379X (imprimé)

1703-8138 (numérique)

Découvrir la revue

Citer ce compte rendu

Bélanger, J. (1981). Compte rendu de [Worker Participation: Sucess and Problems, by Hem C. Jain, New York, Praeger Publishers, 1980, 358 pp.] Relations industrielles / Industrial Relations, 36(3), 690-692.

https://doi.org/10.7202/029191ar

Tous droits réservés @ C Département des relations industrielles de l'Université Laval, 1981
Ce document est protégé par la loi sur le droit d'auteur. L’utilisation des services d'Érudit (y compris la reproduction) est assujettie à sa politique d'utilisation que vous pouvez consulter en ligne.

https://apropos.erudit.org/fr/usagers/politique-dutilisation/ 
suivie d'une brève annotation portant sur l'objet de l'ouvrage, ou encore ses idées maîtresses et/ou sa conclusion. Il nous semble que cela constitue l'apport le plus appréciable de cette récente publication. Compte tenu de la grande quantité de publications sur le sujet, cette bibliographie annotée constitue un instrument de travail utile.

\section{Jacques BÉLANGER}

Université Laval

Worker Participation: Success and Problems, by Hem C. Jain, New York, Praeger Publishers, 1980, 358 pp.

Cet ouvrage du professeur Hem C. Jain, écrit avec la collaboration de Geneviève Laloux Jain, est le fruit d'une période de recherche en Europe, notamment à l'Université catholique de Louvain. Il porte sur les différents mécanismes de participation des travailleurs aux décisions dans l'entreprise dans les pays industrialisés à économie de marché.

Après un chapitre d'introduction consistant en un cadre conceptuel, la première partie porte sur les formes de participation indirecte et la seconde sur la participation directe. Sept des vingt chapitres sont des essais préparés par H.C. Jain, le tout étant complété par une série de treize études de cas réalisées par des collaborateurs (sauf pour le premier cas portant sur la Belgique).

Aux chapitres 2, 3 et 4, l'auteur présente des essais portant sur chacun des principaux types de participation indirecte, soit la représentation des travailleurs aux organes de gestion (traitant surtout de la République fédérale d'Allemagne), les comités ou conseils d'entreprises et la négociation collective. Or si ces chapitres soulèvent un certain intérêt, il ne nous semble pas qu'ils apportent une contribution vraiment originale sur ces sujets. L'auteur travaille à partir de sources secondaires et la plupart des publications auxquelles il réfère sont assez bien connues. Il faut toutefois souligner l'apport de la section portant sur des expériences particulières d'innovation en matière de négociation collective aux États-Unis (pp. 87-95).
Par ailleurs, les études de cas sont susceptibles de nous apporter davantage sur les plans de l'originalité et de l'apport de nouvelles connaissances. Soulignons celles ayant davantage soulevé notre attention. Il faut d'abord mentionner la recherche de $J$. Mansell portant sur des comités patronalouvrier dans deux entreprises canadiennes, soit Supreme Aluminium et Ontario Hydro. Bien que les entreprises, et même les expériences de participation, soient assez difficilement comparables, il s'agit d'une recherche bien réussie, particulièrement dans le cas de Supreme Aluminium. On retiendra particulièrement un élément de conclusion à l'effet que la représentation des travailleurs sur le comité s'avère plus efficace à Cntario Hydro notamment parce que les travailleurs ont moins tendance à craindre la direction, étant protégés par un syndicat relativement fort et indépendant, contrairement à l'autre cas. Une telle conclusion est tout à fait conciliable avec celle de E. Chell dont la recherche porte sur sept cas de représentation de travailleurs au conseil d'administration en GrandeBretagne (cas no 3). En effet, cette recherche permet d'établir une relation positive entre la force du/des syndicats dans l'entreprise et le résultat de l'expérience de participation: 'the relative strength of unionism in the firm was a factor that appeared to influence the degree of involvement of the union in worker participation in the firm and the extent to which the worker-director could be a success or failure' (p. 155). Précisons que cette dernière recherche constitue l'un des meilleurs chapitres du volume. Comme ces expériences dans l'entreprise privée britannique furent évidemment implantées sur une base volontaire et toujours à l'instigation de la direction, l'auteur se penche sur les motifs et les raisons ('rationales') justifiant cette initiative. Il en distingue trois types, quatre des sept cas étant du type qu'il qualifie de 'cosmetic', lequel 'has as its basic tenet the notion that a scheme of participation has been introduced to the firm as a public relations exercice; it is thus shallow and without substance' (p. 144).

Dans la partie portant sur la participation directe, on pourra lire des études sur les 
expériences de Saab-Scania (groupes autonomes de production en Suède) et de Shell Canada à Sarnia. On réfère assez fréquemment à ces expériences dans la littérature sur la qualité de vie au travail.

Parmi les très bonnes études de cas présentées dans ce volume, il faut citer celle effectuée par M.A. Gurdon dans une usine de textile de l'État de New York. Intitulée de façon trop ambitieuse 'An American Approach to Self-Management' elle porte sur un régime d'actionnariat (Employee Stock Ownership Plan). La recherche permit de constater des résultats très positifs quant à la satisfaction des employés, la productivité et la profitabilité après la première année de l'expérience. Toutefois, à partir de la seconde année, on observa des signes de frustration, les nouvelles attentes n'étant pas comblées. De fait, l'accès à la propriété n'avait pas modifié la structure décisionnelle de façon significative. Plusieurs des leçons tirées par Gurdon sont intéressantes, notamment celle à l'effet que la contribution collective des salariés au capital semble offrir de meilleures chances de succès que l'actionnariat sur une base individuelle telle que pratiquée dans ce cas.

Dans un bref chapitre sur l'autogestion, A. Whitehorn présente les résultats d'une recherche réalisée au début des années soixantedix dans quatre usines de la république de Slovénie et trois usines canadiennes, toutes dans la même branche d'activité. Il fait ressortir les principaux aspects positifs et les difficultés observées dans les usines yougoslaves, par comparaison avec la situation prévalant dans les entreprises canadiennes. Sans présenter l'autogestion yougoslave comme une panacée, l'auteur soutient que le processus de démocratisation de l'entreprise est bien engagé et a donné jusqu'ici des résultats significatifs.

Les deux derniers chapitres du volume sont des essais de H.C. Jain. Le premier, intitulé 'Information, Training, and Effective Participation', a déjà fait l'objet d'une publication dans Industrial Relations Journal, vol. 9, no 1 (1978). Dans le chapitre de conclu- sion, portant sur les leçons à tirer de l'expérience européenne, l'auteur argumente à l'effet que: 'if collective bargaining is to remain the main road to worker participation in management in North America, then it is necessary to introduce reforms in the existing bargaining system and to supplement it with other permanent institutional arrangements' (p. 346). À partir d'une position du problème ayant plusieurs traits communs avec celle présentée par Jecchinis dans Relations industrielles en 1979 (vol. 34, no 3), l'auteur suggère que deux éléments du modèle européen méritent d'être considérés chez nous, soit le comité d'entreprise et ce qu'il qualifie de 'European system of tripartite consultative mechanisms at the national level' (p. 350). Il faut noter la prudence de l'auteur qui ne manque pas de souligner les obstacles à une telle réforme, les réticences des parties et l'avantage à procéder sur une base volontaire.

L'ouvrage se termine sur cet argument significatif: 'the socioeconomic challenges confronting both the United States and Canada are grave enough to warrant a concerted action on the part of gouvernment, unions, and management to achieve increased productivity, to regain competitiveness in the international markets, to solve the problems of unemployment and inflation, and to bring about a prolonged period of industrial peace. Before present economic and social problems reach a state of crisis and the government is forced to solve them, it is in the enlightened self-interest of both labor and management to find ways and means to interact more regularly at various levels of the organization and to experiment with new participative approaches that are based on cooperation rather than confrontation' (p. 357). On pourrait se demander si l'auteur est favorable à une véritable réforme structurelle qui soit susceptible de contribuer à démocratiser la prise de décisions dans l'entreprise ou s'il implore cette approche moins conflictuelle et plus consensuelle parce qu'elle pourrait contribuer à la relance de l'économie sans remettre en cause la structure du pouvoir. Dans ce dernier cas, les travailleurs et leurs syndicats pourraient juger que ce ne sont pas tant la vérita- 
ble participation des travailleurs aux décisions et la démocratie dans l'entreprise qui sont en cause mais bien des objectifs traditionnels de l'entreprise privée dans une économie capitaliste.

Il n'est pas facile d'émettre un jugement global sur l'ensemble de ce volume. L'auteur a tout à fait raison lorsqu'il formule l'observation suivante dans sa préface: 'there is a vacuum in the published literature, namely, case studies on the actual operation of legal and voluntary participative schemes in individual companies' (p. VII). Et il précise que ce livre représente un effort pour combler cette lacune. En ce sens, l'objectif a été atteint dans une bonne mesure puisque plusieurs études de cas apportent une contribution appréciable, notamment celles auxquelles nous avons référé de façon particulière. Toutefois, il est fort possible que le lecteur ne soit pas tout à fait satisfait pour autant, justement parce que ce volume ne constitue pas une unité, un ensemble cohérent, mais plutôt une collection d'essais et d'études de cas. Ces études de cas ont été réalisées par plusieurs collaborateurs de différents pays. Leur qualité est variable quant à la méthode et la profondeur de l'analyse. On ne discerne pas de problématique d'ensemble et l'auteur ne tente pas de faire ressortir les rapports, le fil conducteur entre les différentes études de cas. Dans une bonne mesure, les limites de l'ouvrage s'expliquent par son genre et aussi par son objet, puisqu'il touche à une gamme de sujets très divers.

\section{Jacques BÉLANGER}

Université Laval

\section{Equal Employment Policy for Women: Strat- egies for Implementation in the United States, Canada, and Western Europe, edited by Ronnie Steinberg Ratner, Philadelphia, Temple University Press, 1980, 520 pp.}

Equal employment policies for women are a relatively recent phenomenon. During the last ten to twenty years, various facets of equal employment policy have been intro- duced in a increasing number of countries. While the pattern of a separate, restricted and inferior position of women workers continues to be displayed with considerable uniformity across countries, variations exist in methods and stages of implementation of equal employment policy for women.

Ronnie Steinberg Ratner's text is a welcome arrival, offering unique perspectives on the international experience with equal employment policies. Indeed, it represents the first cross-national discussion of equal employment policy for women. Published in 1980 , this book is a set of papers commissioned for a 1978 conference sponsored by the Wellesley College Center for Research on Women. The twenty-two papers provide analytic case studies and critical essays prepared by experts on equal employment policies in Sweden, West Germany, Austria, France, Great Britain, Canada and the United States.

The book is an important contribution to the evolving theory and analysis of equal employment policy. Its major flaw stems from the lack of a common approach to papers prepared by contributors. While Ratner, as editor, has managed to fill in gaps with two strong analytic chapters, one is left with several questions which the papers in varying degree fail to adequately address.

The opening chapter by Ratner provides an examination of the position of women in the seven countries. Aspects of the labour force position of women which are common to all countries are highlighted, such as the high degree of occupational and industrial segregation, rising participation rates of married women, differentially high unemployment of women compared to men, a persistent male-female wage gap and a high degree of part-time work.

The chapter also provides a discussion of the evolution of the two main facets of equal employment policy, equal pay and equal opportunity. Ratner then addresses within this chapter one of the most important topics in the book, namely, the sources of female labour market inequality. Her analysis of the 